\title{
Конкурс інноваційних розробок «СХоди в Майбутне: відзнака молодих науковців у сфері охорони здоров'я та фармацевтики»
}

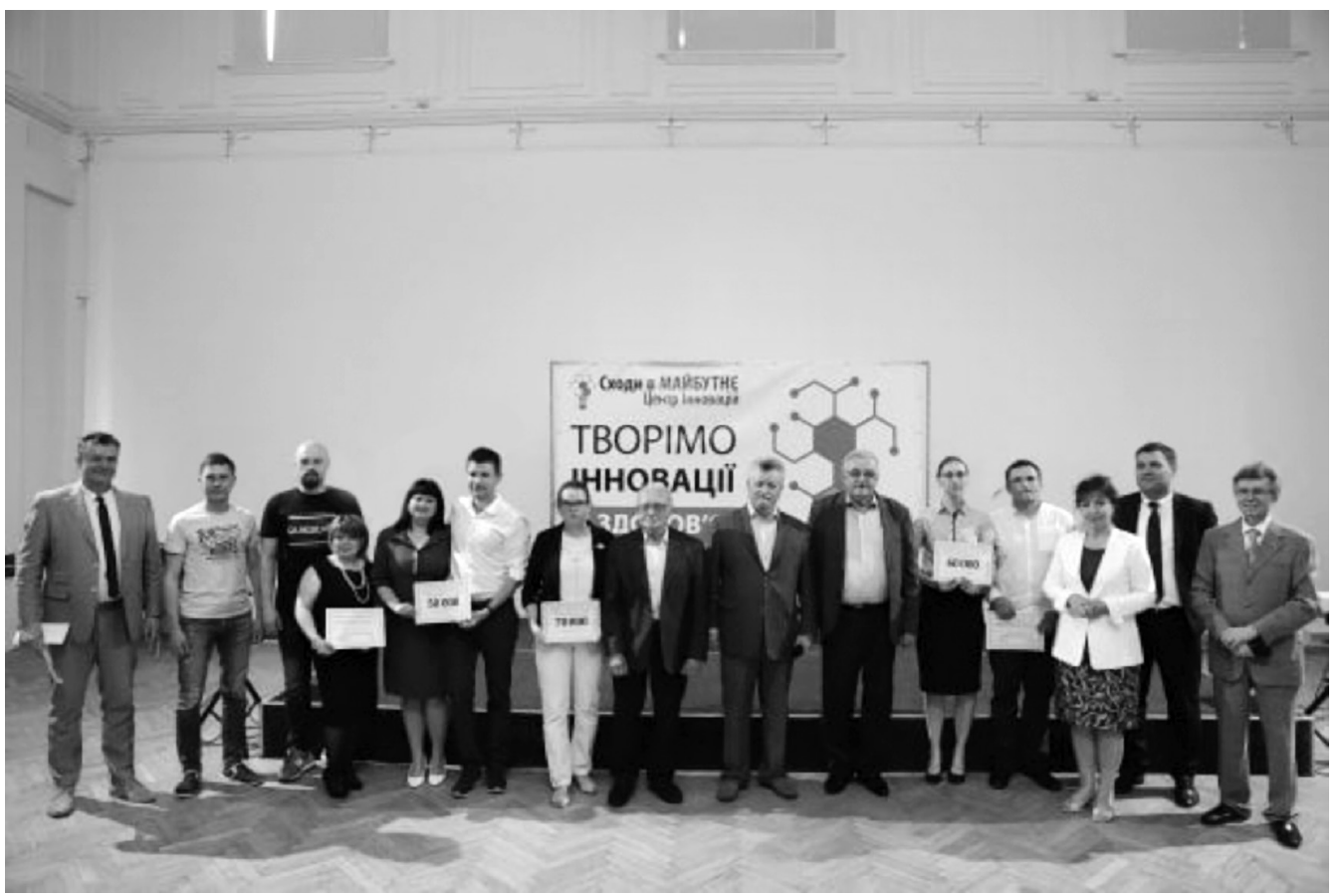

30 травня 2019 року в Києві в Жовтневому Палаці відбувся фінал Конкурсу інноваційних розробок «Сходи в Майбутне: відзнака молодих науковців у сфері охорони здоров'я та фармацевтики», організаторами якого виступили Громадська спілка «Центр інновацій «Сходи у Майбутнє» і Національна академія медичних наук України.

У Конкурсі взяли участь проєкти за темами, що спрямовані на вивчення механізмів розвитку фармакорезистентності, у тому числі до антибіотиків, та їі подолання в лікуванні соціально небезпечних хвороб, зокрема, ВІЛ, туберкульозу тощо, а також на розробку препаратів для лікування вірусних інфекцій з використанням наступних технологій:

- Біотехнологія (Biotechnology);

- Нанотехнологія (Nanotechnology);

- Генна інженерія (Gene engineering);

- Нові молекули і фармкомпозиції (New molecules and pharmaceutical compositions).
Після попереднього відбору проєктів, що відповідали вимогам: інноваційність, можливість технологічної реалізації, інвестиційна привабливість і висока ймовірність впровадження в практику охорони здоров'я, їхні автори та проєктні команди були запрошені до участі в освітній програмі Конкурсу, що мала на меті навчання бізнес-плануванню, підготовці презентацій для потенційних інвесторів, маркетинговим навичкам, взаємодії зі стратегічними партнерами та інвесторами тощо.

Після проходження навчання авторам було запропоновано модернізувати презентації проєктів, використовуючи отримані навички, та представити їх перед журі на фіналі Конкурсу.

До складу журі Конкурсу увійшли:

Голова журі: Віталій Іванович Цимбалюк - академік НАМНУ, президент Національної академії медичних наук України; 
Співголова журі: Дмитро Ілліч Заболотний - академік НАМНУ, віце-президент Національної академії медичних наук України, директор ДУ «Інститут отоларингології ім. проф. О. С. Коломійченка НАМНУ»;

\section{Члени журі:}

Володимир Анатолійович Міхньов член-кореспондент НАМНУ, головний учений секретар Національної академії медичних наук України;

Тамара Іванівна Єрмоленко - доктор фармацевтичних наук, професор, завідувач кафедри фармакології та медичної рецептури Харківського національного медичного університету;

Сергій Олександрович Шкураков заступник директора Департаменту інтелектуальної власності Міністерства економічного розвитку і торгівлі України.

Загалом у фіналі Конкурсу було презентовано 9 інноваційних проєктів.

За рішенням журі перше місце та грошовий приз у 70000 грн було надано Дар’ї Дудіковій (ДУ «Інститут фармакології та токсикології НАМНУ»), автору інноваційного проєкту «Адасепт» - засіб для профілактики та лікування гнійно-запальних процесів шкіри, м'яких тканин та оніхомікозів». Друге місце та грошовий приз у 60000 грн було розділено між двома фіналістами: Оксаною Фалюш (ДУ «Інститут ендокринології та обміну речовин ім. В. П. Комісаренка НАМНУ») за інноваційний проєкт «Спосіб гальмування росту раку передміхурової залози людини на експериментальній моделі» і Василем Сирваткою (Львівський національний університет ім. Івана Франка ) за інноваційний проєкт «Технологія створення композитних нанопрепаратів широкої протимікробної діï».

Третє місце та грошову винагороду в 50000 грн було розділено між двома фіналістами: Любов'ю Білявською (Інститут мікробіології та вірусології ім. Д.К. Заболотного НАНУ) за інноваційний проєкт «Інноваційна модель доклінічних досліджень вірус-асоційованих захворювань людини для розробки дієвих профілактичних і лікувальних противірусних засобів» і Глібом Лазаренком (ДНУ «Науково-практичний центр профілактичної та клінічної медицини» ДУС) за інноваційний проєкт «Адаптація поверхні імплантатів до організму реципієнта».

Також, за рішенням організаторів конкурсу, було встановлено номінацію «Кращий соціальний проєкт» і грошовий приз у 3000 грн, переможцем в якій визначено Людмилу Лейбенко (ДУ «Інститут епідеміології та інфекційних хвороб ім. Л. В. Громашевського НАМНУ») з інноваційним проєктом «Аналіз резистентності вірусів грипу до зареєстрованих хіміопрепаратів» .

Інші конкурсанти отримали призи квитки до Національної опери України iм. Т. Г. Шевченка на різні постановки 3 оперного репертуару червня 2019 року.

Усі конкурсанти отримали Сертифікати учасників конкурсу, а їхні наукові керівники - подяки.

Підготовлено за матеріалами Гроладської спілки «Центр інноваиій «Сходи в майбутнє»:uptofuture.org 